\title{
Development and Validation of Unplugged Activity of Computational Thinking in Science Module to Integrate Computational Thinking in Primary Science Education
}

\author{
Tracy Mensan ${ }^{1 *}$, Kamisah Osman², Nazatul Aini Abdul Majid ${ }^{3}$ \\ ${ }^{1}$ Faculty of Education, National University of Malaysia, Bangi, Malaysia, ${ }^{2}$ Center for Teaching and Learning Innovation, Faculty of Education, National \\ University of Malaysia, Bangi, Malaysia, ${ }^{3}$ Center for Artificial Intelligence Technology, Faculty of Information Science and Technology, National \\ University of Malaysia, Bangi, Malaysia
}

*Corresponding Author: tracymensan@gmail.com

\section{ABSTRACT}

Computational thinking (CT) is increasingly acknowledged as an essential skill to solve problems interdisciplinary. This paper describes the development and validation of the unplugged activity of CT in science (ACTS) module, which is specifically designed to integrate CT. The present study was conducted in five phases: Phase I was composed of needs analysis to elicit respondents' opinions regarding the knowledge of CT and appropriate topic to integrate CT within the year 5 science curriculum. Phase II was the development of the unplugged ACTS module, Phase III was content and face validation of the module, Phase IV was the implementation and Phase V was the evaluation of the effectiveness of the module. The needs assessment indicated that students have never known about CT. The module covered the "Matter" topic for year 5. A content validity index (CVI) was used to quantitatively assess content validity, finding a CVI of more than 0.79 as appropriate. The module was found to have a high mean of validity for content value (CVI $=0.83)$. Expert members have made suggestions that will then be used to develop the module as required. This study concluded that the module has strong validity of the content and can be used to improve CT and science content knowledge among children in primary school.

KEY WORDS: computational thinking; educational module; module development; module validation; primary science

\section{INTRODUCTION}

I $n$ the Fourth Industrial Revolution, the changing contours of the modern world of work are gradually becoming a lived reality for millions of workers and companies around the world (World Economic Forum, 2018). A source of tremendous creativity is the new business models created by disruptive technologies. A reformation of the education and training system is essential for facilitating good work for all in the future. Science and technology are characterized as a principal means to create new jobs for the citizens as a whole in this global market by focusing on augmenting the state of science, technology, engineering, and mathematics (STEM) education to produce more future workforce with the knowledge required to grow new industries(CPGE21, 2007). In response to such reformation, Malaysia has started to introduce computational thinking (CT) into formal education starting, from young learners in primary education. The development of CT in young learners may build a foundation for learners to embrace a systematic problem-solving approach and foster higher-order thinking skills (Falloon, 2016) to all disciplines, including STEM.

CT has been incorporated into formal education in many countries. In Malaysia, where this study took place, implementation of CT in primary schools has been carried out as a part of the new Standard-Based Curriculum for Primary Schools (KSSR), which started in January 2017 (Abas, 2016) with the inclusion of CT will be across all of their subjects. Indeed, there is evidence that students can start learning CT at the primary school level (Ismail et al., 2016; Lye and Koh, 2014; Rijke et al., 2018). However, recent studies indicated that teachers have a weak understanding of CT (Ung et al., 2018) and showed minimal concern but were interested and needed more information on how to apply CT skills in their teaching and learning (T\&L) (Senin et al., 2019). Science subject teachers also need support in planning and designing their science instruction as well as equipping themselves with generic pedagogical knowledge and skills (Osman et al., 2006). Hence, the teachers should be supplied with more relevant knowledge and practices specific to their subject of teaching, including on how to integrate CT in their lesson plan, lesson activities, and lesson assessments. A module can be used to solve this problem.

A module is an instructional package dealing with a single conceptual unit of subject matter and affords the opportunity to develop, evaluate, and use a variety of media to optimize instruction for students on a given topic (Russell, 1974). It also emphasizes the direct involvement of students with learning materials. This will provide real and meaningful experience directly to the students. The previous studies that used a module had effectively increased science literacy and thinking 
skills (Şener and Tü, 2015). Hence, this study developed an educational module, namely, the unplugged activity of CT in science (ACTS) module to enhance the content knowledge of science and to introduce $\mathrm{CT}$ among the children.

\section{LITERATURE REVIEW}

CT was first used by Papert in 1980 and has then been broadly defined by Jeannette Wing in 2006 as a fundamental skill for everyone and should be added to every child's analytical ability; putting CT as important as the 3 Rs basic skills in school which are reading, writing, and arithmetic (Wing, 2006). She further expanded the use of CT beyond computer science discipline to reformulate a seemingly difficult problem to a solvable problem using a collection of fundamental cognitive tools that originated in computing, such as abstraction and decomposition. CT is useful in solving problems and design systems to assist in automating a wide range of intellectual processes. It will be important for the students especially the young children to develop CT skills as the community increasingly dependent in computer technology.

The current study highlights the two main approaches to teach these skills in schools, which are through plugged-in activities using computer programming activities and unplugged activities that do not require the use of programming by software or digital devices. Although the use of plugged-in activities is the most common strategy to teach CT skills in schools (Brackmann et al., 2017; Lye and Koh, 2014; Sengupta et al., 2013; Weintrop and Wilensky, 2017), unplugged activities can be a good approach to introduce students especially young learners to CT (Looi et al., 2018). A variety of unplugged activities has been carried out such as board games (Apostolellis et al., 2014; Kuo and Hsu, 2020), puzzles (Gibson, 2012), logic games (Curzon, 2013), or physical movements (Waterman et al., 2020) to represent and understand CT. Unplugged activities have been an approach used by several researchers to introduce students to CT before they take part in any coding or programming activities (del Olmo-Muñoz et al., 2020) including in the formal science education. In Malaysia, unplugged and plugged-in activities are introduced in Information Technology and Communication curriculum for year 6 . However, the implementation of unplugged $\mathrm{CT}$ in teaching science concepts for primary education is underexplored. Teaching science concept using CT unplugged approach in young students may provide an opportunity for the students to strengthen their foundation in CT skills (Brackmann et al., 2017; Prottsman, 2014) and improve their understandings in science concept (Peel et al., 2019) simultaneously. In this study, introduction to CT among year 5 students through flowcharts and thinking maps to organize information to solve the task will provide better preparation for students to learn programming in year 6 .

Therefore, this study investigated an educational module using unplugged activities in science learning based on the standard-based curriculum for primary (KSSR) for the children to introduce students to CT skills and improve science literacy in this digital age. It was an 8-h program conducted in a formal science lesson at school, twice weekly, for $60 \mathrm{~min}$ per session during regular school hours. CT skills were integrated into the chapter of "Matter" for year 5. Four CT skills that have been operationally defined in Table 1 were utilized.

\section{METHODOLOGY}

\section{Study Design}

This study focused on the development of instructional material in the form of a module for 11-year old children. There were five phases involved, Phase I: Needs assessment, Phase II: Development of the unplugged ACTS module, Phase III: Validation of the unplugged ACTS module, Phase IV: Implementation of the unplugged ACTS module, and Phase V: Evaluation of effectiveness of the unplugged ACTS module. Permission from the Ministry of Education and the Sarawak State Education Department was obtained before the commencement of data collection. The study hoped that the validated unplugged ACTS module could be offered as reference material to guide primary school teachers once the module had shown to be effective in improving primary school children's science content knowledge and CT. The content of the unplugged ACTS module could be included in the school science textbook to improve students' science knowledge and $\mathrm{CT}$. The effectiveness of the validated module in improving children's science knowledge and CT was evaluated before implementation.

\section{Phase I: Needs Assessment}

In this phase, a need assessment was conducted to identify problems in a classroom and determine whether intervention in instruction and training was the correct course of action (McArdle, 1998). This is usually the first step to implement effective change in an educational setting. This phase determined the most difficult chapter that would be the focus of the module. The KSSR for Science Primary 5 is based on the Ministry of Education Malaysia. According to the syllabus, in overall, there are 12 chapters to be covered over the school year. The chapters are Scientific Skills, Science Room Rules, Life Processes in Animals, Life Processes in Plants, Energy,

\begin{tabular}{ll}
\hline Table 1: Operational definition of CT skills \\
\hline CT skill & Operational definition \\
\hline Decomposition & $\begin{array}{l}\text { Breaking down a set of tasks or problems into } \\
\text { smaller and manageable parts }\end{array}$ \\
Pattern recognition & $\begin{array}{l}\text { Identifying patterns in characteristics, processes, } \\
\text { or relationships within a task or problem to } \\
\text { structure knowledge and solving a similar task or } \\
\text { problem with the same strategy }\end{array}$ \\
Abstraction & $\begin{array}{l}\text { Highlighting necessary details and eliminating } \\
\text { unnecessary details to understand a task or } \\
\text { problem better } \\
\text { Plgorithmic thinking }\end{array}$ \\
problem as a set of step-by-step instructions
\end{tabular}


Properties of Light, Electricity, Heat, Matter, Acid and Alkali, Earth, Moon, and Sun and Technology.

A survey was conducted to analyze the opinions of science teachers and students. Two survey forms were created, one for the teacher and one for the students. The survey form for the teacher had two items: Item 1 - Give your opinion on the level of difficulty for students to understand the chapters; and Item 2 - Give your opinion on the level of appropriateness for the integration of CT on the chapters. Meanwhile, the survey form for the students had only one item: Item 1 - Give your opinion on the level of difficulty to understand the chapter. In completing the survey form, respondents were required to choose responses either 1 - Very easy, 2 - Easy, 3 - Moderate, 4 -Difficult, and 5 - Very difficult. The chapter with the highest mean for the level of difficulty and within the appropriate level for the integration of $\mathrm{CT}$ was considered as the chapter that will be developed in the unplugged ACTS module.

\section{Phase II: Development of Unplugged ACTS Module}

\section{Module structure}

The unplugged ACTS module was structured to provide a systematic guideline for the science teachers to conduct the science lesson using unplugged activities. The module was written in the Malay language. As the module would be implemented in rural schools, it was developed using appropriate language in an easy-to-understand format. Introduction of four CT skills, namely, decomposition, pattern recognition, abstraction, and algorithmic thinking that had been validated by experts, was highlighted at the beginning of the module. The order of the activities in the module was arranged according to the order of the syllabus. Every activity included a lesson plan, lesson activity, and lesson assessment.

\section{Module content}

The module was designed to fulfill the aim of Science Standard Curriculum that is to instill interest and develop creativity among pupils through experience and investigation so as to master knowledge in science, scientific skills, thinking skills, and scientific attitudes and values. Therefore, relevant literature, textbook, and science modules published by the Ministry of Education and international studies on unplugged CT in science education had been reviewed to develop content for the module. Principles derived from constructivist learning theories and inquiry-based learning play an important role in guiding the module development. Thinking tools that included flowcharts and thinking maps were incorporated in the activities (Figures 1 and 2). The materials and examples presented were contextual and realistic. According to Piaget's stages of development, children at this concrete operational stage can form concepts, see relationships, and solve problems but only as long as they involved objects and situations that are familiar (Slavin, 2009). Therefore, interactive and hands-on activities were integrated into every activity to encourage children to learn and involve actively. As social cognitive theory was used to design the unplugged ACTS module, collaborative learning was emphasized in every

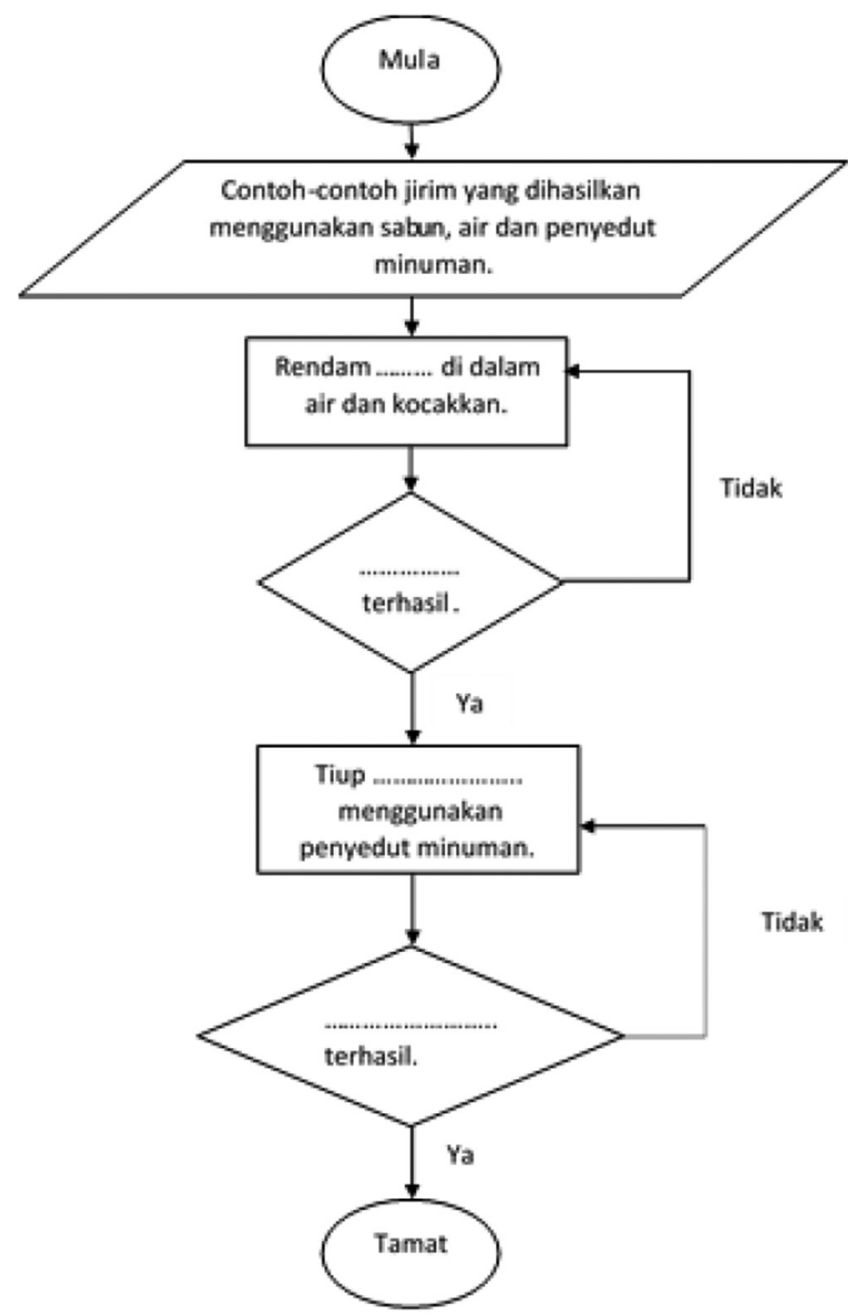

Figure 1: Example of flowchart used in the module

TIGA KEADAAN JIRIM AIR

Arahan: Lersikan air kepada contoh jirim yang lain dengan melengkapkan jadual di bawah. Lukiskan susunan zarah bagi keadasn jirim yang berkaitan.

\begin{tabular}{|c|l|}
\hline $\begin{array}{c}\text { Keadaan } \\
\text { jirim: }\end{array}$ & \\
\hline $\begin{array}{c}\text { Contoh } \\
\text { jirim: }\end{array}$ & \\
\hline
\end{tabular}

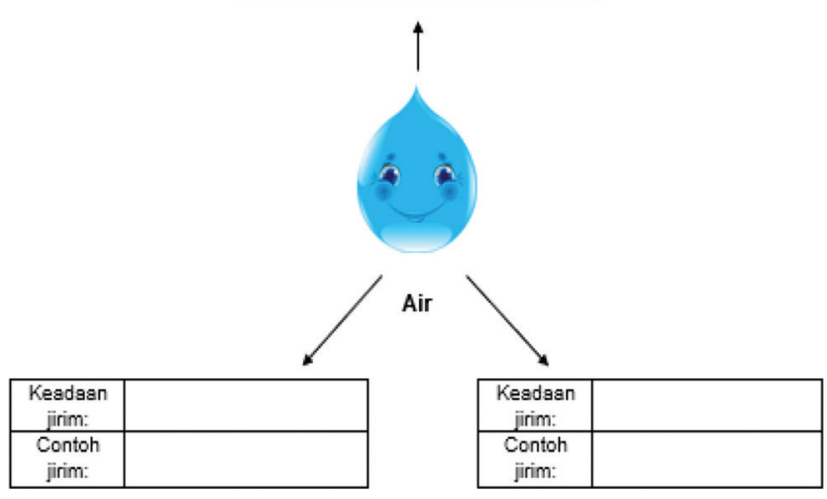

Figure 2: Example of thinking map used in the module 
activity to optimize the learning in children. We hypothesized that, following the implementation of the unplugged ACTS module, the children's science knowledge and positive attitude along with the positive reinforcements from environmental factors such as social support from teacher and peers would motivate the children as well as increase their CT skills for the organization of information to solve the problem systematically. The pedagogical approach used to implement the science module was constructivism teaching. This method of instruction helps children to relate better the information learned in science T\&L to their daily life. Every lesson in this module enabled the children to work collaboratively to help the children learn social skills, support each other's learning processes, and value each other's opinions and inputs.

\section{Phase III: Content and Face Validation of Unplugged ACTS module \\ Content and face validation by expert pane/s}

A panel of experts evaluated the completed unplugged ACTS module for appropriateness and relevance of content. At least five panels were required to avoid chance agreement. Our interdisciplinary panel was composed of two experts from the science computer field, two science module experts, and two experienced science teachers. The experts on our panels were deliberately selected to obtain diverse ideas from different specializations.

Content validation was an independent review process using a content validation form. The content validation form was created based on five conditions that had been clarified by Russell (1974) for a module to be considered as having good content validity. The five conditions were: (1) Targeted population achieved, whereby the module produced takes into account the backgrounds and behaviors of the focus group; (2) circumstances in which the module is applied are successful and satisfactory; (3) the time allocated for the subject to complete the module is sufficient; (4) there is an improvement in the performance or achievement of subjects after the module has been completed; and (5) there is an attitude change toward excellence (i.e., attitudes or behaviors change) after undergoing the activities in the module. Therefore, the unplugged ACTS module was evaluated in six aspects (i.e., presentation of the module, curriculum, T\&L theory, and approaches, content, and CT skills) that were related to content validity. There were 43 indicators to be judged by the experts for content validity.

In the report of module development, the most extensively used approach for content validity is the content validity index (CVI). The CVI expresses the proposition of agreement on the relevancy of each indicator, which is between zero and one. It has been proposed that an index of 0.80 or higher is required for an indicator to be judged as relevant. Judgment on each indicator was made as follows: If the CVI was equal and higher than 0.78 , the indicator was deemed appropriate; if the CVI was between 0.70 and 0.78 , the indicator needed revision; and if the CVI was $<0.70$, the indicator was eliminated (Polit et al., 2007). The panel of experts examined each indicator and rated the components on a scale ( 1 for "strongly disagree;" 2 for "disagree," 3 for "neutral;" 4 for "agree;" and 5 for "strongly agree"). Other than CVI, content validity performance equal and more than $70 \%$ indicated high content validity (Tuckman and Waheed, 1981). Sidek and Jamaludin (2005) stated that the percentage of performance content validity could be calculated by dividing the total expert score (x) with a maximum score and multiply it with 100 .

\section{Face validation by language expert}

The instrument aimed for face validation had three aspects (i.e., text, graphic, and language) with five units in each aspect to be judged by the language expert. The same scale as in content validity was used. The expert was requested to review the unplugged ACTS module and rate from 1 (indicated strongly disagree) to 5 (indicated strongly agree) on each indicator of the face validation instrument. For face validation, the indicator with at least a $75 \%$ positive response is considered validated (Tuckman and Waheed, 1981).

\section{Phase IV: Implementation of Unplugged ACTS Module}

An intensive training on CT and how to carry out the activities in the module was provided for the teachers before the pilot study took place in the participating primary schools. The training was designed to build the teacher's competency in CT through unplugged approach, with an emphasis on integrating the skills of CT in an inquiry-based science learning environment. The training had three main components, which were introduction to CT, unplugged CT and facilitating a CT-science lesson. The researcher demonstrated some of the activities with the teachers to give them the opportunity to experience the activities in the module from the perspective of a learner. Meanwhile, the same curriculum content covered in the experimental school was delivered in another control school. However, the activities in the control school were delivered without the use of unplugged ACTS module as a resource and in keeping with the traditional method.

\section{Phase V: Evaluation of Effectiveness for Unplugged ACTS Module}

The participants of this pilot study were year 5 students in two rural government primary schools in one of the divisions in the state of Sarawak, Malaysia. A total of 67 students consisting of 32 male and 35 female students were selected as the study sample with 31 students participating in the experimental group and the 36 participating in the control group. Permission and approval were sought from the Division of the Research Department, Ministry of Education to conduct the study in both schools. The headmasters, teachers, and students were informed of the background and procedure of the study. Anonymity of the participating schools, teachers, and students involved in this research were upheld. The study itself employed a quasi-experimental design using quantitative method. Two instruments were administered to the students before their involvement in the implementation of the module. The two instruments were as follows: 
- Science content knowledge test: Twelve multiple choice items and one subjective item developed by the researcher in the context of Malaysia based on KSSR. The validity of the content was checked by subject expert. The item content validity indices were reported as 1.00 . Reliability (KR-20) of the test was 0.7.

- CT test: Fifteen multiple choice items from the International Bebras Contest. The Bebras Tasks are a set of activities designed to promote the interest of CS from a CT perspective and can be administered to individuals without any prior programming experience (RománGonzález et al., 2017). Figure 3 shows one example of the Bebras task used in the $\mathrm{CT}$ test.

\section{FINDINGS AND DISCUSSION}

\section{Analysis of Needs Findings}

A total of 58 science teachers and 76 students from primary schools in Sarawak participated in answering the analysis questionnaires. The mean age of the students was 11 years

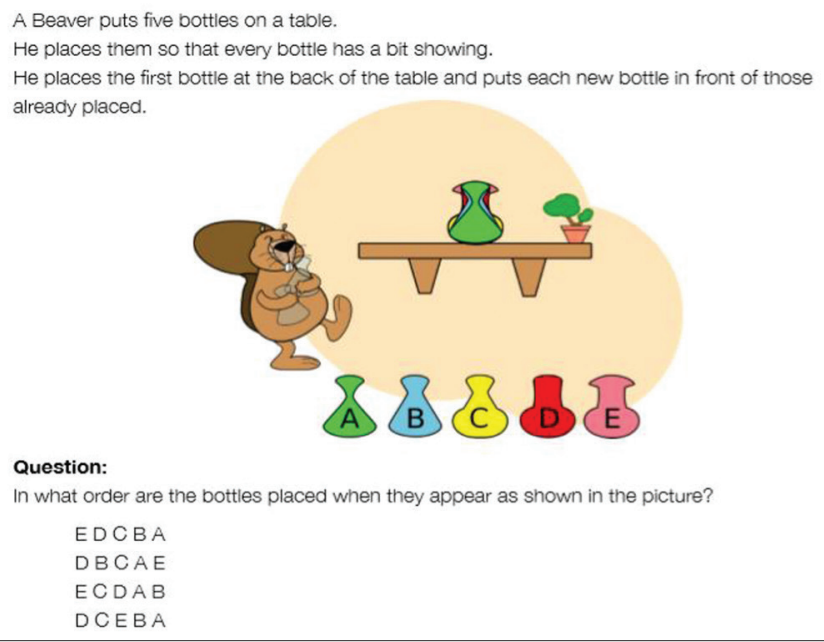

Question:

In what order are the bottles placed when they appear as shown in the picture?

EDCBA

$D B C A E$

$E C D A B$ DCEBA

Figure 3: Example of Bebras task used in computational thinking test old. A total of $37.70 \%$ of students were boys, and $62.30 \%$ of students were girls. About $41 \%$ of teachers had 10-19 years of teaching experiences, $15.52 \%$ of teachers had more than 20 years of teaching experiences, and $8 \%$ of teachers had 5-9 years teaching science experiences. The need analysis showed that the students had never learned about CT.

Table 2 shows the level of difficulties and appropriateness for the integration of CT among all the topics in KSSR Science for Primary 5. Findings indicated that the topic "Matter" had the highest level of difficulties for both group of respondents and was appropriate (M less than 3.00) for integration of CT. Based on the literature, the concept of matter was one of the core concepts of science to understand better the scientific phenomena such as the water cycle (Hadenfeldt et al., 2016). However, there is little concrete guidance provided on how the concept of matter should be taught (Samarapungavan et al., 2017). Therefore, the topic to be the focus for the module was "Matter."

\section{Design and Validity of the Unplugged ACTS Module}

The unplugged ACTS module of constructivism theory was developed as a learning resource for primary five science T\&L. It was designed based on the conception of hands-on and collaborative learning activity with emphasizing two levels of inquiry (structured and guided inquiry) and four CT skills (decomposition, abstraction, pattern recognition, and algorithmic thinking). Flowchart and thinking maps had been introduced as the thinking tool to visualize the thinking process. The selected topic to be focused on was "Matter." Eight unplugged activities had been planned to introduce CT and increase science content knowledge. The module was equipped with three main components; (a) lesson plan, (b) lesson activity, and (c) lesson worksheets to foster CT. The module structure of the development results is presented in Table 3.

The unplugged ACTS module has 72 pages, with the front cover, back cover, table of content, introduction, list of references, and activities of the module are summarized in Table 4. Learning time for every unit is $60 \mathrm{~min}$. CT skills were integrated into every lesson.

Table 2: Primary five science topic level of difficulties and appropriateness for integration of CT

\begin{tabular}{lccc}
\hline Topics & \multicolumn{2}{c}{ Level of difficulties } & Appropriateness for integration of CT M (teachers) \\
\cline { 2 - 3 } & $\boldsymbol{M}$ (Teachers) & $\boldsymbol{M}$ (Students) & 2.14 \\
\hline Scientific skills & 3.13 & 2.17 & 1.80 \\
Science room rules & 1.58 & 1.29 & 1.80 \\
Life processes in animals & 2.72 & 1.89 & 1.91 \\
Life processes in plants & 2.83 & 2.04 & 2.01 \\
Energy & 3.16 & 2.53 & 2.00 \\
Properties of light & 2.02 & 2.37 & 2.00 \\
Electricity & 3.17 & 2.71 & 2.05 \\
Heat & 3.24 & 2.49 & 2.32 \\
Matter & 3.67 & 3.15 & 2.03 \\
Acid and Alkali & 3.09 & 2.71 & 2.18 \\
Earth, moon and sun & 3.50 & 2.48 & 2.01 \\
Technology & 3.05 & 2.68 & \\
\hline
\end{tabular}

CT: Computational thinking 


\begin{tabular}{llll}
\hline \multicolumn{3}{l}{ Table 3: Structure of unplugged } & ACTS \\
\hline Components & Lesson plan & $\begin{array}{l}\text { Lesson } \\
\text { activity }\end{array}$ & $\begin{array}{l}\text { Lesson } \\
\text { worksheet }\end{array}$ \\
& & Title & Title \\
\hline Structure & Theme/topic & Learning & Instruction \\
& Length of time & standard & Assessment \\
& Content standard & Assignment & question \\
& Learning standard & Application & Application of CT \\
& Learning objective & Ap CT & \\
Computational thinking & of & \\
T\&L activity & & \\
\hline
\end{tabular}

ACTS: Activity of computational thinking in science, T\&L: Teaching and learning

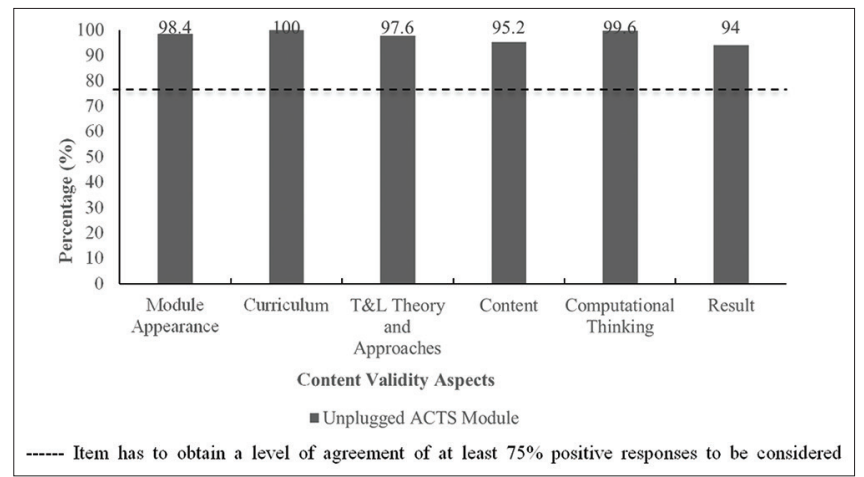

Figure 4: Performance for content validity

The content validation of the unplugged ACTS module required no major corrections. All the six aspects obtained a CVI higher than 0.79 , indicating an excellent level of agreement between the expert panel members for content validity. The performance for content validation (Figure 4) indicated more than $70 \%$ level of agreement. Therefore, the module fulfilled the requirement of a learning module and can be used as a guide for science teachers in their T\&L.

As shown in Table 5, all three face validity aspects achieved a level of agreement higher than $75 \%$. The unplugged ACTS module was considered to have achieved face validity for the target group.

The experts judged the module positively. They considered the module important for the promotion of science knowledge and CT skills of the children. With the development and validation of the module completed, the module will undergo evaluation in the real setting of T\&L. The validated unplugged ACTS module will be used in the formal science T\&L. A pilot study has been conducted to determine the effectiveness of the module and reported below.

\section{Effects of Unplugged ACTS Module on Science Content Knowledge and CT Skills}

The research data were presented in the form of pre-test and post-test scores which were analyzed statistically using oneway Analysis of Variance (ANOVA) with significance level established at $5 \%$. The independent variable was the unplugged ACTS module intervention. The experimental group had been using the intervention while the control group did not. The dependent variable comprised scores on science content knowledge for the topic of matter and scores on CT test. The error variance for the students' scores in the pre-test indicated that it was equal across the experimental group $(n=31)$ for the science content knowledge $F(1,65)=0.52, \rho>0.05$ and in the CT test $F(1,65), \rho>0.05$, indicating that the two groups had homogeneity of variance.

Table 6 presents the descriptive statistics for the pre-test and post-test of science content knowledge and CT skills including the mean score for the two groups. For science content knowledge, the results obtained showed that the post-test mean score for experimental group was higher than the control group. This indicates that the students in the experimental group outperformed the students in the control group. The same pattern of results was obtained for the CT skills where the post-test mean score for the experimental group was higher than the control group. Further analysis using one-way ANOVA showed that there was no significant different in students' content knowledge $\mathrm{F}(1,65)=0.148, \mathrm{p}=.702)$ and in students' CT skills $\mathrm{F}(1,65)=0.728, \mathrm{p}=0.397)$.

This study successfully developed a validated unplugged ACTS module. The mean CVI was 0.83 , and overall performance content validity was $97.47 \%$, thus confirming content validity. This process of adapting educational materials to the suggestions of experts is an essential step to produce a useful module for science education activities.

The design of science lesson activities using the inquirybased approach and CT should be able to provide a positive impact on students' learning that is reflected in their academic achievements and their ability to solve the problem (HmeloSilver, 2004; Veloo et al., 2013). Collaborative learning was integrated into all eight activities in the module to enable concrete operational students to enhance their CT skills provided by dynamic group and teacher support in cooperative environments. Each group consisted of 4-5 students and lesson was facilitated by a science teacher. According to Vygotsky, a less skillful individual is better able to develop a more complex level of understanding and skill than he/she could independently through collaboration, direction or help or an expert or a more capable peer (Vygotsky, 1978). Hands-on activities through implementation of various $\mathrm{T} \& \mathrm{~L}$ methods such as experiments, discussion, and simulations were among the most emphasized activities by science teachers (Lee et al., 2000 ) and motivated students more in learning science (Osman et al., 2013; Şener and Tü, 2015).

The module was designed to foster CT skills. Each activity in the module provided a task or problem that could stimulate CT skills. For example, the ability to think algorithmically was stimulated by presenting step-by-step instruction or solution to the problem using a flowchart. The transformation from structured to guided inquiry activity allowed the students to be familiar with the construction of the flowchart. At the end of the module, the students should be able to present their 


\begin{tabular}{|c|c|c|c|c|}
\hline ACTS & Topics & Learning standards & CT Skills & CT activities \\
\hline 1 & States of matter & $\begin{array}{l}\text { State that matter can exist as solid, } \\
\text { liquid, and gas } \\
\text { Classify the examples of materials/ } \\
\text { objects into solid, liquid, and gas }\end{array}$ & Abstraction & $\begin{array}{l}\text { Students abstract the arrangement of particles in } \\
\text { solid, liquid, and gas from the given text. They then } \\
\text { model the arrangement of each type of matter using } \\
\text { the ping pong balls on the egg tray }\end{array}$ \\
\hline 2 & Properties of solid & $\begin{array}{l}\text { Characterizing the properties of solid } \\
\text { by carrying out activities to show it; has } \\
\text { mass; occupy space; has a fixed volume, } \\
\text { and has fixed shape }\end{array}$ & Pattern recognition & $\begin{array}{l}\text { Students identify the pattern of solid properties using } \\
\text { marbles and stone as examples based on the provided } \\
\text { flowchart }\end{array}$ \\
\hline 3 & Properties of liquid & $\begin{array}{l}\text { Characterizing the properties of a liquid } \\
\text { by carrying out activities to show it; has } \\
\text { mass; occupy space; has a fixed volume, } \\
\text { and has fixed shape }\end{array}$ & $\begin{array}{l}\text { Decomposition } \\
\text { Algorithmic thinking }\end{array}$ & $\begin{array}{l}\text { Students outline the procedure to show the property } \\
\text { of liquid and decompose the procedure to step-by- } \\
\text { step instruction using a flowchart. The flowchart will } \\
\text { be used by another group to test its functionality }\end{array}$ \\
\hline 4 & $\begin{array}{l}\text { The natural water } \\
\text { cycle }\end{array}$ & $\begin{array}{l}\text { Relate the changes in states of water } \\
\text { with the formation of clouds and the } \\
\text { phenomena of rain } \\
\text { Generate ideas on the importance of the } \\
\text { natural water cycle } \\
\text { Explain observations using sketches, } \\
\text { Information Technology and } \\
\text { Communication, writing or verbally }\end{array}$ & $\begin{array}{l}\text { Abstraction } \\
\text { Algorithmic thinking }\end{array}$ & $\begin{array}{l}\text { Based on a text titled "The Journey of a Water } \\
\text { Molecule," students abstract the sequence of } \\
\text { changes in states of water molecule started from } \\
\text { the evaporation of water from the ground until it } \\
\text { becomes rain and repeat the cycle }\end{array}$ \\
\hline 5 & $\begin{array}{l}\text { The importance of } \\
\text { water resources }\end{array}$ & $\begin{array}{l}\text { State natural water resources such as a } \\
\text { river, lake, well, and spring } \\
\text { Explain the importance of maintaining } \\
\text { the cleanliness of water resources }\end{array}$ & Abstraction & $\begin{array}{l}\text { Based on an online news article review about the } \\
\text { polluted water in Sarawak, students abstracted the } \\
\text { necessary information and organized them using a } \\
\text { thinking map }\end{array}$ \\
\hline
\end{tabular}

ACTS: Activity of computational thinking in science

\begin{tabular}{lcc}
\hline Table 5: Face validation & & \\
\hline Aspect & Mean & Percentages \\
\hline Texts & 4.75 & 95.0 \\
Graphic & 4.4 & 88.0 \\
Language & 4.4 & 88.0 \\
Average & 4.52 & 90.3 \\
\hline
\end{tabular}

Table 6: Science content knowledge: Pre-test and posttest means by group

\begin{tabular}{llccc}
\hline $\begin{array}{l}\text { Dependent } \\
\text { variables }\end{array}$ & Group & Pre-test mean & Post-test mean & $\mathbf{n}$ \\
\hline $\begin{array}{l}\text { Science } \\
\text { content } \\
\text { knowledge }\end{array}$ & Experimental & 30.968 & 42.903 & 31 \\
$\begin{array}{l}\text { Computational } \\
\text { thinking skills }\end{array}$ & Experimental & 42.581 & 41.250 & 36 \\
& Control & 36.852 & 44.516 & 31 \\
\hline
\end{tabular}

algorithmic thinking by constructing a flowchart in solving a task or problem, formally or in daily life application.

The strength of this study was that the unplugged ACTS module was customized to the needs of KSSR learning standards. The module was pilot-tested among potential students and had its content validated by an expert panel before being implemented in an intervention study. One of the limitations of this study was that the unplugged ACTS module was developed in only one language, i.e., Malay. Translating the module into English would minimize language barriers. This is a crucial future work as Sarawak will implement dual language program for Science and Mathematics subjects starting the year 2020.

As a formal science lesson has very limited T\&L time with 2-3 $\mathrm{h} /$ week, the unplugged ACTS module was designed as an $8 \mathrm{~h}$ lesson. Introduction to basic CT skills and flowchart been taught only in an hour before the implementation of the module. Therefore, it is recommended to have a comprehensive $5 \mathrm{~h}$ workshop for the teachers and students before the use of modules in the classroom. This may increase the effectiveness of the module.

\section{CONCLUSIONS}

The development of the unplugged ACTS module will be the foundation for a longer-term learning progression to integrate $\mathrm{CT}$ into the science curriculum. The module was developed specifically for use in the T\&L of primary five science, to enhance science content knowledge and CT skills. The module was content validated and can be used as a reference by the science teachers to diversify their instructional strategies in improving systematic thinking skills among the children within an active and collaborative learning environment. The content of the module has the potential to be incorporated into science education textbooks to benefit more children. A few studies have shown that the existing textbook is the main resource for formal science education. However, the science textbook does not integrate CT skills in an inquiry-based science lesson. The module was developed to cover these weaknesses to prepare the children with the $21^{\text {st }}$ century fundamental CT skills in an active and collaborative environment. 


\section{REFERENCES}

Abas, A. (2016). Computational Thinking Skills to be Introduced in School Curriculum Next Year. New Straits Times. https://www.nst.com.my/ news/2016/08/164732/computational-thinking-skills-be-introducedschool-curriculum-next-year.

Apostolellis, P., Stewart, M., Frisina, C., \& Kafura, D. (2014). RaBit EscApe: A board game for computational thinking. ACM International Conference Proceeding Series, 2014, 349-352.

Brackmann, C.P., Román-González, M., Robles, G., Moreno-León, J., Casali, A., \& Barone, D. (2017). Development of computational thinking skills through unplugged activities in primary school. In: Proceedings of the $12^{\text {th }}$ Workshop on Primary and Secondary Computing EducationWiPSCE '17. New York: ACM. pp. 65-72.

CPGE21. (2007). Rising Above the Gathering Storm Energizing and Employing America for a Brighter Economic Future. Washington, D.C, United States: National Academic Press.

Curzon, P. (2013). Unplugged Computational Thinking for Fun. Available from: https://www.publishup.uni-potsdam.de/opus4-ubp/frontdoor/ deliver/index/docId/8257/file/cid07_S15-27.pdf. [Last retrieved on 2020 Apr 16].

del Olmo-Muñoz, J., Cózar-Gutiérrez, R., \& González-Calero, J.A. (2020). Computational thinking through unplugged activities in early years of primary education. Computers and Education, 150, 103-832. Available from: https://www.sciencedirect.com/science/article/abs/pii/ S0360131520300348. [Last retrieved on 2020 Mar 27].

Falloon, G. (2016). An analysis of young students' thinking when completing basic coding tasks using Scratch Jnr. On the iPad. Journal of Computer Assisted Learning, 32(6), 576-593.

Gibson, J.P. (2012). To children of all ages. In: Proceedings of the $17^{\text {th }}$ Annual SIGCSE Conference on Innovation and Technology in Computer Science Education (ITiCSE'12). New York: ACM. pp. 34-39.

Hadenfeldt, J.C., Neumann, K., Bernholt, S., Liu, X., \& Parchmann, I. (2016). Students' progression in understanding the matter concept. Journal of Research in Science Teaching, 53(5), 683-708.

Hmelo-Silver, C.E. (2004). Problem-based learning: What and how do students learn? Educational Psychology Review, 16(3), 235-266.

Ismail, A., Hayati, M., Yatim, M., Sahabudin, N.A., Zuhaidah, N., \& Zain, M. (2016). Keupayaan murid sekolah rendah mempelajari dan menerokai bahasa pengaturcaraan visual capability of primary school pupils in learning and exploring visual programing language. Journal of ICT in Education, 3, 89-97.

Kuo, W.C., \& Hsu, T.C. (2020). Learning computational thinking without a computer: How computational participation happens in a computational thinking board game. Asia Pacific Education Researcher, 29(1), 67-83.

Lee, K.W.L., Tan, L.L., Goh, N.K., Lee, K.W.L., Chia, L.S., \& Chin, C. (2000). Science teachers and problem solving in elementary schools in Singapore. Research in Science and Technological Education, 18(1), 113-126.

Looi, C.K., How, M.L., Longkai, W., Seow, P., \& Liu, L. (2018). Analysis of linkages between an unplugged activity and the development of computational thinking. Computer Science Education, 28(3), 255-279.

Lye, S.Y., \& Koh, J.H.L. (2014). Review on teaching and learning of computational thinking through programming: What is next for K-12? Computers in Human Behavior, 41, 51-61.

McArdle, G.E.H. (1998). Conducting Needs Analysis. Menlo Park, CA: Crisp Publications.

Osman, K., Halim, L., \& Meerah, S.M. (2006). What Malaysian science teachers need to improve their science. Eurasia Journal of Mathematics Science and Technology Education, 2(2), 58-81.

Osman, K., Hiong, L.C., \& Vebrianto, R. (2013). 21 ${ }^{\text {st }}$ Century biology: An interdisciplinary approach of biology, technology, engineering and mathematics education. Procedia Social and Behavioral Sciences, 102, 188-194.
Peel, A., Sadler, T.D., \& Friedrichsen, P. (2019). Learning natural selection through computational thinking: Unplugged design of algorithmic explanations. Journal of Research in Science Teaching, 56(7), 983-1007.

Polit, D.F., Beck, T., \& Owen, S.V. (2007). Focus on research methods is the CVI an acceptable indicator of content validity? Appraisal and recommendations. Research in Nursing and Health, 30(4), 459-467.

Prottsman, K. (2014). Computer science for the elementary classroom. ACM Inroads, 5(4), 60-63.

Rijke, W.J., Bollen, L., Eysink, T.H. S., \& Tolboom, J.L.J. (2018). Computational thinking in primary school: An examination of abstraction and decomposition in different age groups. Informatics in Education, 17(1), 77-92.

Román-González, M., Moreno-León, J., \& Robles, G. (2017). Complementary tools for computational thinking assessment. In: Proceedings of International Conference on Computational Thinking Education (CTE 2017). Hong Kong: Hong Kong Convention and Exhibition Centre. pp. 154-159.

Russell, J.D. (1974). Modular Instruction : A Guide to the Design, Selection, Utilization and Evaluation of Modular Materials. Vol. 1. Oklahoma: Burgess Publishing Company.

Samarapungavan, A., Bryan, L., \& Wills, J. (2017). Second graders' emerging particle models of matter in the context of learning through model-based inquiry. Journal of Research in Science Teaching, 54(8), 988-1023.

Şener, N., \& Tü, C. (2015). Improving science attitude and creative thinking through science education project: A design, implementation and assessment. Journal of Education and Training Studies, 3(4), 57-67.

Sengupta, P., Kinnebrew, J.S., Basu, S., Biswas, G., \& Clark, D. (2013). Integrating computational thinking with $\mathrm{K}-12$ science education using agent-based computation: A theoretical framework. Education and Information Technologies, 18(2), 351-380.

Senin, S., Nasri, N.M., Senin, S., \& Nasri, N.M. (2019). Teachers' concern towards applying computational thinking skills in teaching and learning. International Journal of Academic Research in Business and Social Sciences, 9(1), 296-310.

Sidek, M.N., \& Jamaludin, A. (2005). Pembinaan Modul: Bagaimana Membina Modul Latihan dan Modul Akademik. Malaysia: Penerbit Universiti Putra Malaysia.

Slavin, R.E. (2009). Educational Psychology: Theory and Practice. $9^{\text {th }}$ ed. London, United Kingdom: Pearson.

Tuckman, B.W., \& Waheed, M.A. (1981). Evaluating an individualized science program for community college students. Journal of Research in Science Teaching, 18(6), 489-495.

Ung, L.L., Saibin, T.C., Naharu, N., \& Labadin, J. (2018). An evaluation tool to measure computational thinking skills: Pilot investigation. Herald NAMSCA, 1, 606-614.

Veloo, A., Perumal, S., \& Vikneswary, R. (2013). Inquiry-based instruction, students' attitudes and teachers' support towards science achievement in rural primary schools. Procedia Social and Behavioral Sciences, 93(2002), 65-69.

Vygotsky, L. (1978). Mind in Society: The Development of Higher Psychological Processes. United States: Harvard University Press.

Waterman, K.P., Goldsmith, L., \& Pasquale, M. (2020). Integrating computational thinking into elementary science curriculum: An examination of activities that support students' computational thinking in the service of disciplinary learning. Journal of Science Education and Technology, 29(1), 53-64.

Weintrop, D., \& Wilensky, U. (2017). Comparing block-based and textbased programming in high school computer science classrooms. $A C M$ Transactions on Computing Education, 18(1), 1-25.

Wing, J.M. (2006). Computational thinking. Communications of the ACM, 49(3), 33-35.

World Economic Forum. (2018). The Future of Jobs Report. Geneva, Switzerland: Report, World Economic Forum. 